A N NALES

UNIVERSITATIS MARIAE CURIE-SKŁODOWSKA LUBLIN - POLONIA

VOL. XXXV

SECTIO FF

$1-2017$

\title{
EMILIA RYDZEWSKA
}

Uniwersytet Jagielloński

\section{Człowiek wobec książki. Zwrot ku rzeczom - zwrot ku książkom? O projektowaniu, historii i książce jako obiekcie pożądania}

The Man and Book Paradigm. The Turn to Things - the Turn to Books?

On Design, History, and Books as an Object of Desire

\section{WPROWADZENIE}

Z pytaniem „,czym jest rzecz?” nic właściwie nie można poczać - tak w Pytaniu o rzecz stwierdził Martin Heidegger (2002). Rzecz można definiować wielorako: jako zwykły przedmiot użytku codziennego, fetysz, obiekt kultu, dzieło sztuki, przyjaciela, powiernika (lalki dla dzieci) etc. Z pewnością książka jako rzecz odpowiada każdemu z przytoczonych tutaj znaczeń rzeczy: jednym książka może służyć jako ciężarek do przygniatania ciast, dla innych staje się dekoracją mieszkania, a dla pozostałych jest świętością (średniowieczne manuskrypty otaczano kultem). Natomiast książka artystyczna czy dawna na aukcjach dzieł sztuki osiąga często niebotyczne kwoty, np. egzemplarz Bay Psalm Book wydrukowany w 1640 roku sprzedano na nowojorskiej aukcji za 14 milionów dolarów (The Bay Psalm Book Sale, 2013). Książka była również, jak uczy historia, ukojeniem zmysłów - dla bywalców Biblioteki Aleksandryjskiej stała się lekarzem duszy, Petrarka tylko w bibliotece potrafił odnaleźć wewnętrzny spokój, Biernat z Lublina pisał (1522): „Którzy ciem siedzą z księgami/ Nie mogą być nigdy sami,/ Aże kiedy w ciżbie siedzą/ Tam dopiero sami będą". Obecnie książka pełni ważną funkcję terapeutyczną (biblioterapia), jak wykazuje Ewa Tomasik (1994).

Książka jako przedmiot towarzyszyła człowiekowi od wynalezienia pisma i przyjmowała różnorodne formy, np. glinianych tabliczek z pismem klinowym, 
jak te z kolekcji Kirkora Minassiana, papirusowych zwojów z egipskimi hieroglifami, kawałków bambusa powiązanych trawą w Chinach (np. Sztuka wojny Sun Zi czy stele z glifami Majów), przez zwoje, a później kodeksy pergaminowe. Następnie pojawiła się książka papierowa, drukowana, a współcześnie plik elektroniczny zapisany w różnych formatach uwarunkowanych oprogramowaniem używanych przez człowieka urządzeń (komórek, tabletów, laptopów, czytników etc.).

Książki rozumiane jako obiekty traktowane są przez naukowców w zależności od ich zainteresowań badawczych. I tak: historyków literatury najbardziej interesuje treść dzieła, co jest oczywiście zrozumiałe - autor rzadko ma wpływ na formę zewnętrzną swojej pracy; edytorów i grafików interesuje szata graficzna, układ typograficzny, czcionka, rodzaj papieru, oprawy, okładki, obwoluty - wtedy często postać autora odchodzi w zapomnienie, gdyż ważniejsi są wydawcy oraz ich oficyny; historyków i historyków sztuki również zajmuje forma danego egzemplarza, jak funkcjonuje on na tle danej epoki, ponadto interesuje ich książka jako dzieło sztuki. W niniejszej pracy podjęto próbę refleksji nad tym, co sprawia, że książka od tak wielu lat jest przedmiotem pożądania. Z tego względu w artykule postanowiono przyjrzeć się pokrótce różnym podejściom do projektowania książek, przywołać zjawisko „bibliomanii” i kolekcjonerstwa, a także podjęto próbę zdefiniowania książki luksusowej oraz postrzegania książki jako dzieła sztuki.

\section{KRÓTKA HISTORIA KSIĄŻKI I PROJEKTOWANIA}

Już w czasach przed Gutenbergiem „ludzie książki” prześcigali się w doskonaleniu ówczesnych ich form. Co znajduje odzwierciedlenie w opracowaniu Sary Ayad i Rodericka Cave'a (2015). Książka rękopiśmienna przybierała wygląd zależny od mód, jakie panowały w danym kręgu kulturowym. W Mezopotamii do zapisu tekstu stosowano numerowane gliniane tabliczki o prostokątnym kształcie, w których porządku strzegł kustosz ${ }^{1}$. Gliniana tabliczka była w praktyce niezniszczalna, gdyż nie groziły jej pożary; w ogniu utrwalała się jak cegła. Z kolei tabliczki drewniane, żelazne i kamienne cieszyły się popularnością w starożytnej Grecji i Rzymie, przypominały wyglądem współczesne notesy, często też pełniły funkcję notatników - autorzy zapisywali na tabliczkach pokrytych woskiem za pomocą rylca swoje pomysły dzieł. W Egipcie produkowano zwoje papirusowe, których produkcja była dość skomplikowanym procesem; wyróżniano papirus hieratyczny - lepszy, stosowany do tekstów religijnych, papirus kupiecki - gorszej jakości, używany np. do pakowania towarów. Zwoje owijano w pergaminowe obwoluty, wiązano rzemykami i przechowywano je w capsach i bibliothecach.

${ }^{1}$ Kustosz był oznaczeniem kolejności za pomocą powtórzenia ostatniego wiersza tekstu na dole tabliczki. 
Rywalizacja Biblioteki Aleksandryjskiej i Pergamońskiej sprawiła, że papirus został wyparty przez inny materiał piśmienniczy - pergamin (odpowiednio przygotowana skóra). Jest to materiał stosowany współcześnie do druków luksusowych (zwłaszcza najdelikatniejsza jego odmiana - welin), który nie pali się, jest mniej podatny na wilgoć, nie pleśnieje, farba nie reaguje z pergaminem, więc można ją ścierać i tworzyć nowe dzieła na dawnym materiale. Poszukiwanie coraz doskonalszych rozwiązań dla pierwszych książek wskazuje na ważną funkcję, jaką pełniły one w życiu społecznym i kulturowym człowieka.

Jak czytamy u Barbary Bieńkowskiej i Haliny Chamerskiej (1987:48-62), najważniejsze $\mathrm{w}$ produkcji książki było wynalezienie papieru przez ministra rolnictwa Tsai Luna w Chinach w 105 r.n.e. Papier dotarł później do Arabii, następnie do Hiszpanii oraz innych państw europejskich. Był materiałem trwałym, tańszym w produkcji niż pergamin, dlatego stopniowo wypierał inne sposoby zapisu tekstu. Forma książki zależała bowiem głównie od materiału, na jakim utrwalano przekaz. Istotne były także oprawy, które chroniły „blok” książki - najpiękniejsze wykonywano w państwach arabskich, często ze szlachetnych gatunków skór, natomiast dla mniejszych książek projektowano oprawy kopertowe. Równie ciekawe są książki bizantyńskie, dzięki którym możemy poznać malarstwo antyczne. W Bizancjum książki traktowano z największym szacunkiem: oprawy kodeksów rzeźbiono, wykonywano w całości z blachy bądź emalii, bogato zdobiono (dekoracje celkowe czy żłobkowe). Najpiękniejszym zwieńczeniem książki rękopiśmiennej są iluminowane średniowieczne manuskrypty. Bogato zdobione za pomocą różnorodnych środków: ozdobnych linii i inicjałów oraz coraz bardziej skomplikowanych wzorów, rozbudowanych bordiur, floratur, inicjałów, miniatur, licznych ilustracji, złoceń. Dobrym przykładem sztuki iluminatorskiej jest z pewnością ewangeliarz z Kells. Z kolei Codex rotundus z 1480 roku odznacza się bardzo ciekawym jak na owe czasy rozwiązaniem: tekst spisano na 266 stronach o średnicy $9 \mathrm{~cm}$, grubość książki to tylko $3 \mathrm{~cm}$, całość dzieła spinają trzy misternie wykonane klamry z gotyckim pismem (Pięć wyjątkowych ksiązek, 2015).

Książki traktowano z największym szacunkiem i troską, jako coś, co pozostanie pamiątką, a także stanowi o kunszcie danej epoki. Widziano w nich również przejaw religijności - co prawda nie wszystkie były obiektem kultu jak Biblia, ale wierzono, że obcowanie z książkami leczy duszę, pomaga w uspokojeniu się. Już w czasach starożytnych uważano, że książki mogą pomagać - na portalu przy wejściu do Biblioteki Aleksandryjskiej umieszczono napis Psyches iatreion (,sanatorium dla umysłu”). W epokach następnych to przeświadczenie się tylko umacniało, co znajduje poświadczenie w pracy Marii Wichowej (2013:49-66).

Inkunabuły (pierwsze książki drukowane) wzorowane były na książce rękopiśmiennej, co skutkowało stosowaniem różnorodnych czcionek typograficznych używanych w drukach piętnastowiecznych. Jak podaje Helena Szwejkow- 
ska (1987), stosowano ponadto zdobnictwo ręczne, np. rubrykowanie, inicjały, iluminacje i miniatury; kroje czcionek imitowały różnego rodzaju pismo ręczne w zależności od terenu i czasu powstawania dzieła, tj. przywoływały formą pisma gotyckie - teksturę, rotundę, bastardę, szwabachę, antykwę, gotyko-antykwę. Później, w latach 70. XV wieku, drukarze uwalniali się od standardów rękopisów, zmniejszyła się także liczba krojów pisma, co więcej już w XVI wieku ustalono podstawowe czcionki (antykwa, kursywa, szwabacha i fraktura). Co ciekawe, już wtedy ustalono, jakiego kroju użyć w publikacji zależnie od docelowej grupy odbiorców. Antykwy używano w łacińskich tekstach, kursywy dla dokumentów papieskich, szwabachę przeznaczoną do druków reformatorskich, a ozdobna i ,porozciągana” fraktura służyła między innymi do składu romansów rycerskich (Szwejkowska, 1987:80-90). Z wynalazkiem Gutenberga narodziło się zapotrzebowanie na różnorodne formy książek, które miały przyciągać czytelników - zmniejszył się format tomów, ustalono znaki porządkowe, takie jak paginacja, kustosze, sygnatury, spis treści, oficyny wydawnicze zabiegały o najpoczytniejszych autorów, giserzy wytwarzali coraz bardziej finezyjne kroje pisma. Do zdobienia książek zatrudniano najlepszych artystów: Łukasza Cranacha, Jana Holbeina, Albrechta Dürera czy Godfryda Tory'ego.

W XVII wieku Niderlandy wiodły prym w sztuce drukarskiej, a zdobnictwo książek było ściśle związane ze stylem barokowym. Sztuka książki nieco zamarła, ale należy podkreślić fakt, że nie odeszła w zapomnienie. Nie dbano o jakość druku, wydawano książki o lichej szacie zewnętrznej, na kiepskim papierze, przez który często przebijała farba. Można to tłumaczyć okresem pełnym napięć - Europę ogarnęły liczne konflikty wewnętrzne i zewnętrzne.

Styl książek osiemnastowiecznych zdominowany został przez barok, rokoko oraz neoklasycyzm. W zdobnictwie wykorzystywano popularne ówcześnie architektoniczne motywy: girlandy, koronki, tympanony, kolumny etc. XVIII wiek to przede wszystkim ożywienie francuskiej sztuki książkowej oraz nastawienie na bogatszych czytelników, co wiązało się z rozwojem ruchu bibliofilskiego. Pojawiły się winiety z pejzażami i scenami rodzajowymi, emblematy korespondujące $\mathrm{z}$ treścią książki, a także nowe motywy zdobnicze m.in. cul-de-lampe ${ }^{2}$ (Bieńkowska i Chamerska, 1987:80-110).

Wiek XIX przyniósł książce kolejne zmiany, co opisała Janina Wiercińska (1986). Wiąże się to z działalnością Bractwa Prerafaelitów, a zwłaszcza Williama Morrisa i jego towarzyszy tworzących oficyny wydawnicze Kelmscott Press. Morris odnowił sztukę graficzną: zaprojektował nowe czcionki, w tym m.in. Golden Type, wzorując się na średniowiecznych manuskryptach, dopracował stronicę książki drukowanej, zapełniając ją licznymi motywami roślinnymi i antropomorficznymi. Książki Morrisa, Johna Ruskina, Stephena i Crane’a do dzisiaj służą

${ }^{2}$ Cul-de-lampe - jeden z rodzajów winiety, typ ornamentu umieszczanego na ostatniej stronie rozdziału książki, najczęściej przybierał formę trójkąta skierowanego wierzchołkiem do dołu. 
za wzór dla wielu projektantów, grafików i typografów. Francja również przeżywała w tym czasie złoty wiek czarnej sztuki: powstawały książki dla każdej grupy odbiorców i na każdą kieszeń. Rozwijała się francuska szkoła patrzenia na obrazy, co przełożyło się na ilustrację książkową i nowe tendencje projektowania, pojawiły się bogato ilustrowane publikacje dla dzieci, które są wzorcem dla grafików opracowujących tomy przeznaczone dla najmłodszego kręgu odbiorców. Rozwijały się biblioteki publiczne, powstawały koła czytelnicze, ludzie kupowali coraz chętniej duże ilości książek, otaczali się nimi w prywatnych bibliotekach i gabinetach (Wiercińska, 1986).

Projektowanie książek przeszło w XX wieku rewolucję; osoby, takie jak Jan Tschichold (Nowa typografia), Robert Bringhurst (Elementarz stylu w typografii), Adrian Frutiger (Człowiek i jego znaki) odmieniły spojrzenie na projektowanie. Wyznaczyli oni pewne standardy w drukowaniu, projektowaniu rozkładówek, wytłumaczyli, jak wykorzystywać różne wielkości i grubości krojów, aby prosto i czytelnie przekazać informacje, łącząc przy tym dotychczasowe tradycje typograficzne z nowoczesnymi możliwościami. Projektowanie książek związało się ściślej z tworzeniem mebli, przedmiotów codziennego użytku. Wspólnym mianownikiem stały się: prostota, podobna kolorystyka (biały, czarny, czerwony), surowość formy połączona z wygodą użytkowania.

W XXI wieku, kiedy na rynek książki weszły czytniki i ebooki, wielu wydawców zaczęło zadawać sobie pytanie, czy to już koniec ery tradycyjnego czytelnictwa. Zwolennicy ebooków wskazują na takie zalety, jak: brak kłopotów z nadbagażem, wiele tytułów w jednym miejscu (zależne tylko od pojemności czytnika), mniej problemów z obciążonym kręgosłupem, połączenie książki tradycyjnej, odtwarzacza muzyki i wideo etc. Jednak zwolennicy książki papierowej mają więcej przyjemności z czytania tradycyjnego i przytaczają argumenty na korzyść papierowego tomu: ebook nie pachnie (zapach książki przy czytaniu to jedno z ważnych doznań), jakość czytania książki tradycyjnej jest nieporównywalna z czytaniem ebooka, książki drukowane cieszą oko etc. (Ebook kontra książka papierowa, 2015). Z ebookami wiąże się także zjawisko kradzieży praw autorskich i własności intelektualnej - po wstukaniu w okno wyszukiwarki pożądanego przez nas tytułu bez problemu odnajdziemy wersję elektroniczną danego wydania, która powielana jest przez wielu użytkowników. Książki papierowe najczęściej kupujemy, wypożyczamy z biblioteki bądź od znajomych, co oznacza, że ktoś zapłacił autorowi i wydawcy za prawo korzystania z ich dzieła.

\section{POŻĄDANIE KSIĄŻEK}

Książka od zawsze była kojarzona z dociekaniem prawdy i wiedzą, jest niejako symbolem całości Wszechświata. W historię losów świata wpisane są tak ważne księgi, jak: Księga Zmartych, „księga ksiąg” - Biblia, Księga Zakonu, Księga 
Losów, Księga Proroctwa, Księga Życia... Chęć posiadania w bibliotece białych kruków, wydań niezwykłych, oryginalnych, stawała się pragnieniem wielu ludzi, co w swojej pracy udowadniała Małgorzata Lebda (2013).

Aby w pełni zrozumieć znaczenie książki jako obiektu pożądania, słuszne wydaje się przybliżenie fenomenu ,gorączki bibliofilskiej”, towarzyszącej człowiekowi od czasów Biblioteki Aleksandryjskiej. Warto przywołać tu postaci najbardziej kontrowersyjnych zbieraczy, którzy właściwie całe życie poświęcili kolekcjonowaniu książek, a także pokazać, jak czytanie stało się jednym z ważniejszych motywów w sztuce. Zamiłowanie do zbierania książek nasiliło się w czasach renesansu. Już wtedy pasja bibliofilska, wykraczająca poza zwykły utylitaryzm, opanowała ludzi świeckich, a skryptoria klasztorne nie mogły zaspokoić tego popytu. Zasobność pierwszych bibliotek była niewielka, po wynalazku Gutenberga upodobanie do kolekcjonowania książek znacznie wzrosło, stawało się uzależnieniem, a nawet wpędzało bibliofilów w długi. Warto przywołać za Januszem Gruchałą (2002:80-100) przypadek Vespazjana da Bisticci, jednego z pierwszych dystrybutorów książek, którego przed katastrofą uratowali Medyceusze czy historię ubogiego księdza Tommasa Parentucellego, który, już jako papież Mikołaj V, utworzył Bibliotekę Watykańską. Jednym z największych księgozbiorów w renesansie mógł pochwalić się Federigo Montefeltre, jego kolekcja była porównywana z papieską (ponad 900 tomów).

W epoce odrodzenia pojawił się również portret czytelnika z książką utrwalony w sztukach plastycznych. W National Gallery średnio na co piątym obrazie występuje książka. Najpopularniejszymi motywami były: Zwiastowanie czytająca Maryja u Duccia di Buoninsegna wskazuje na mesjańską zapowiedź Izajasza; Jan Chrzciciel ze zwojem (charakterystycznym dla proroków); sceny modlitw mnichów - księgi liturgiczne; czytająca św. Maria Magdalena - kontemplacja; postaci świętych były często ukazywane z książką w jednej ręce, a w drugiej z przypisanym im atrybutem, liczne scenki rodzajowe: wnętrze z książkami, Madonny z książką częste u Rafaela, Maryja ucząca Jezusa czytać (Gruchała, 2002:148-150).

W całej Europie zaczęły powstawać okazałe biblioteki dworskie i królewskie:

Począwszy od Filipa Augusta, aż po Karola V, wszyscy królowie Francji wykazywali zamiłowania bibliofilskie. Założycielem królewskiej biblioteki był w XIV wieku Karol V, który zgromadził w Luwrze ponad 1000 rękopisów. Jego prawnuk Ludwik XII przyczynił się do znacznego powiększenia księgozbioru m.in. o bibliotekę Sforzów. W 1537 roku wprowadzono we Francji instytucję obowiązkowego egzemplarza bibliotecznego (Lebda, 2013).

Najwięksi polscy bibliofile to również jedni z najsłynniejszych „książkołapów” (złodziei książek) oraz twórcy pierwszych publicznych bibliotek: Józef Andrzej Załuski, Adam Kazimierz Czartoryski, Tadeusz Czacki, Edward Raczyński i Joachim Lelewel. 
W XIX wieku, wraz z ruchem odnowy pięknej książki, intensywniej rozwijał się rynek antykwaryczny i bibliofilski. Na przełomie XIX i XX wieku w środowisku francuskim ciekawą i barwną postacią był Octave Uzanne - pisarz, wydawca, dziennikarz i bibliofil. Zwrócił on uwagę, w przeciwieństwie do współczesnych mu bibliofilów, na potrzebę tworzenia nowych edycji luksusowych. Podczas przygotowywania książki do druku ściśle współpracował z najlepszymi grafikami, giserami, producentami papieru i artystami (zwłaszcza z symbolistami i przedstawicielami wczesnego Art Nouveau); tworzył związki bibliofilskie, a także napisał i wydał wiele tytułów związanych z bibliofilstwem: Caprices d'un bibliophile (Kaprysy bibliofila), Contes pour les bibliophiles (Opowieści dla bibliofilów), w których zawarł nieco prorocze opowiadanie La fin des livres, gdzie zapowiedział koniec ery książki drukowanej. Uzanne miał różnorodne zainteresowania: kobieca moda, liternictwo, polityka, nowoczesne technologie (takie, jak fonografia, fotografia i kinematografia), nowe techniki drukarskie - uważał że rozwój techniki spowoduje upadek tradycyjnej książki (Silverman, 2004:239-284).

W kontekście postrzegania książki jako obiektu pożądania należałoby wspomnieć o okresach w historii Polski, w których „głód książki” był niezwykle wyraźny, a mianowicie o: dobie niewoli narodowej, okresach zaborów, czasach wojennych oraz późniejszym kryzysie w Polsce Ludowej. Zapotrzebowanie na książki stale wzrastało, a ich dostępność była ograniczona przez: działalność cenzury, represje (zsyłki na Sybir, więzienie, kary grzywny), brak środków finansowych na druk i rozprowadzanie egzemplarzy. Aby ów „głód” zaspokoić, wypracowywano wiele sposobów obchodzenia wspomnianych trudności (przemyt, bibuła, drugi obieg, druk podziemny). Najbardziej pożądano dzieł wieszczów narodowych - Adama Mickiewicza, Cypriana Kamila Norwida, Juliusza Słowackiego - oraz Kornela Ujejskiego, Juliana Ursyna Niemcewicza, Seweryna Goszczyńskiego. Szeroko ten temat ukazała Ewa Skorupa (2004:60-140).

Czy mitologia książki staje się we współczesnym świecie coraz słabsza, czy ograniczają ją inne sztuki, zwłaszcza postmodernizm i kultura masowa oraz, co najważniejsze, wzrastająca liczba osób nieczytających książek? Można odnieść takie wrażenie, jednak wydaje się, że upadek książki jest daleki i nierealny. Zmieniają się nośniki tekstu, a mimo to biblioteki, księgarnie i kolekcje nadal istnieją i są potrzebne. Hobby bibliofilskie również wydaje się nieśmiertelne. Wciąż rodzą się ludzie, którzy poświęcają życie książce bądź zajmuje ona w ich życiu bardzo ważne miejsce. Wystarczy przywołać nazwiska ośmiu największych bibliofilów XXI: pisarza, filozofa i bibliofila Umberto Eco, amerykańskiego profesora, humanisty Richarda A. Mackseya, księgarza i pisarza Larry'ego McMurtry'ego, hinduskiego mistyka Osho, lektora Borghesa Alberta Mangueli, redaktora Otto Penzlera, projektanta mody Karla Lagerfelda i autora powieści fantastycznych Neila Gaimana (Ośmiu słynnych bibliofilów i ich biblioteki, 2013). Bibliofilstwo i „bibliomania" znajdują odzwierciedlenie także w języku. W 1896 roku Uzanne wy- 
dał Dictionnaire Bibliophilosophique, typologique, iconophilesque, bibliopegique et bibliotechnique à l'usage des Bibliognostes, des Bibliomanes et des Bibliophilistins - jak można zauważyć, sam tytuł słownika wskazuje na fakt, że Francuzi potrzebowali doprecyzowywania zjawisk związanych z bibliofilstwem, co więcej, wydaje się, że ich ukucie było conditio sine qua non mówienia o książce w ogóle. W języku angielskim również da się odnaleźć podobne określenia: bibliospher, bibliodemon, biblioclast, bibliobibule, bibliolater, bibliomancer etc. Wydaje się, że pojawienie się polskojęzycznych odpowiedników jest tylko kwestią czasu.

\title{
KSIĄŻKI LUKSUSOWE, KSIĄŻKI ARTYSTYCZNE - DZIEŁA SZTUKI
}

Potrzebę wytwarzania pięknych, luksusowych książek zasygnalizowano na Warsztatach Wiedeńskich na początku XX wieku (Sudjic, 2013:132):

\begin{abstract}
Maszyna pracuje pilnie i zapełnia nasze regały kiepsko wydrukowanymi tomami, a kryterium jej działania jest taniość. Niemniej każdy wykształcony człowiek powinien czuć się zawstydzony tą obfitością. Z jednej bowiem strony łatwość produkcji prowadzi do obniżenia poczucia odpowiedzialności, z drugiej zaś obfitość skutkuje zdawkowością. Jak wiele książek tak naprawdę posiadamy? Czy nie powinniśmy otrzymać ich na najlepszym papierze, oprawione w doskonałą skórę? Czy może zapomnieliśmy, że miłość, z jaką książka została wydrukowana, opatrzona ilustracjami i oprawiona, tworzy zupełnie inny rodzaj relacji pomiędzy nią i nami, i że obcowanie z pięknymi rzeczami czyni nas pięknymi?
\end{abstract}

Dejan Sudjic określił apel warsztatowców jako ,jedno z najbardziej narcystycznych i przejmujących uzasadnień nowoczesnego kultu luksusu" (Sudjic, 2013:132).

Trudno zdefiniować pojęcie książki artystycznej i luksusowej, gdyż wiele zależy od spojrzenia i zamiaru artysty oraz czytelnika. Z pewnością są to tomy przeznaczone dla wąskiego grona odbiorców, które potrafi docenić pracę projektantów, grafików, drukarzy oraz introligatorów. Są to edycje, w których respektuje się wszelkie zalecenia dobrego wydania: odpowiednio dobrany papier, przemyślane rozmieszczenie kolumny tekstowej, ilustracji oraz innych ozdobników - najczęściej opierających się na zasadach złotego podziału.

Czy książka może być dziełem sztuki? Z pewnością takim dziełem jest już wspomniany pięknie zdobiony ewangeliarz z Kells; za dzieło sztuki można z powodzeniem uznać dokonanie XIX-wiecznej francuskiej sztuki drukarskiej Ewangelie na niedziele $i$ święta, które wyszły z oficyny wydawniczej Léona Curmera, edycje luksusowych książek młodopolskich Stanisława Wyspiańskiego, Edwarda Okunia czy Zdzisława Dębickiego; przykłady można by mnożyć w nieskończoność. Coraz prężniej rozwijają się muzea książek. Na uwagę zasługuje Muzeum Książki Artystycznej w Łodzi, założone przez Jadwigę i Janusza Try- 
znów, miłośników i twórców książki artystycznej, oraz prężnie rozwijające się wydawnictwa faksymiliów.

Książki stają się również bardzo ważnym narzędziem ekspresji artystycznej. Ciekawym przykładem jest projekt Mickey Smith (Książka jako przedmiot pożadania, 2012), która opisuje go w ten sposób:

Nie dotykam, nie doświetlam ani nie manipuluję książkami [...] - chcę je dokumentować takimi, jakimi je znajduję, w stosach ułożonych przez bibliotekarza lub ostatniego nieznanego czytelnika. Skupiam się na prostych, prowokacyjnych tytułach, które wykraczają poza grzbiety książek, na których się pojawiają.

\section{CO MÓWIĄ KSIĄŻKI O CZYTELNIKACH? PODSUMOWANIE}

Sannah Kvist (2012) przygotowała interesujący projekt o rzeczach, które niejako „tworzą" człowieka. Sudjic (2013:130) z kolei zadawał pytanie, co mówią o nas przedmioty. Wypadałoby to pytanie uszczegółowić i zapytać: co mówią o nas, czytelnikach, książki. Z pewnością wiele. Istotne jest, czy weźmiemy z półki Lalę Jacka Dehnela w twardej oprawie i będziemy mogli czytać ją w domowym zaciszu, ponieważ ciężko jest nosić taki egzemplarz w torbie, czy jednak wybór padnie na wersję w miękkiej okładce, która będzie dużo lżejsza, lecz szybciej się zniszczy. A może wybierzemy ebooka, dzięki czemu książka ta znajdzie się pośród tysiąca innych na jednym nośniku. Pierwszy wybór wskazuje na osobę, która lubi mieć w swoim domu czy bibliotece piękne półki z ładnie oprawionymi książkami, typ dawnego bibliofila, zbieracza; drugi pokazuje jednostkę pochłaniającą kilka książek w tygodniu, podczytującą je w tramwajach, autobusach, pociągach, ale nie na tyle nowoczesną, by sprawić sobie czytnik i z niego korzystała, lubiącą podczas lektury łączyć różne doznania zmysłowe: zapach papieru, dotykanie jego faktury, sporządzanie ołówkiem notatek na marginesach, docenianie projektu graficznego i typograficznego. Z kolei przypadek trzeci sugeruje, że odbiorca może być typowym, nowoczesnym molem książkowym albo zwyczajnym gadżeciarzem. To jedynie luźna interpretacja pewnych zachowań społecznych - jednak ciekawe wydaje się, ile da się odczytać z książkowych preferencji czytelników.

Bjørnar Olsen (2010:20) pokazał, że im silniej jesteśmy związani z przedmiotami w sensie konsumpcyjnym, tym bardziej koncentrujemy się na reprezentacji, dostrzegając w rzeczach metafory bądź ikony. Wydaje się, że książka jest również taką metaforą, co udowodniła i udowadnia nadal historia drukarstwa, czytelnictwa oraz ludzi związanych z książką. Książka stała się symbolem wiedzy, tajemnicy, mądrości, motywem przewodnim w sztukach i literaturze etc. (Słownik symboli, 1991:176-179). Co z kolei świadczy o tym, że kiedy przyglądamy się rzeczom konstruującym świat, nie możemy zapominać o książkach, które towarzyszą człowiekowi od najmłodszych lat. 


\section{BIBLIOGRAFIA}

Arct, Michał. (1926). Piękno w książce. Warszawa: Wydawnictwo M. Arcta.

Ayad, Sara, Cave, Roderick. (2015). Historia książki. Od glinianych tabliczek po e-booki. Warszawa: Arkady.

Bąbiak, Grzegorz. (2013). Piękna książka na ziemiach polskich u schyłku XIX wieku. Sztuka Edycji, 2, s. 19-30.

Bieńkowska, Barbara, Chamerska, Halina. (1987). Zarys dziejów książki. Warszawa: Centrum Ustawicznego Kształcenia Bibliotekarzy.

Biernat z Lublina. (1522). Kto mituje księgi, nie miewa tęskności. Pobrano z: http://staropolska.pl/ renesans/biernat_z_lublina/Wybor_bajek_01.html (dostęp: 20.06.2016).

Bringhurst, Robert. (2007). Elementarz stylu w typografii. Tłum. Dorota Dziewońska. Kraków: d2d.

Ebook kontra książka papierowa. Pobrano z: http:/warto-nie-warto.pl/ebook-kontra-ksiazkapapierowa/ (dostęp: 20.06.2016).

Frutiger, Adrian. (2010). Człowiek i jego znaki. Tłum. Czesława Tomaszewska. Kraków: d2d.

Gruchała, Janusz. (2002). Iucunda familia, librorum. Humaniści renesansowi w świecie książi. Kraków: Universitas.

Heidegger, Martin. (2002). Czym jest rzecz. Przyczynek do Kantowskiej nauki o zasadach transcendentalnych. Tłum. Janusz Mizera. Warszawa: KR.

Kamisińska, Dorota. (2007). Książka jako dzieło sztuki. Estetyka i Krytyka, 12, s. 73-86.

Komza, Małgorzata. (2003). Muzea sztuki książki. Acta Universitatis Wratislaviensis, 2560, Bibliotekoznawstwo, XXIV, s. 255-268.

Konieczna, Ewelina J. (2004). Arteterapia w teorii i praktyce. Kraków: Oficyna Wydawnicza Impuls.

Książka jako przedmiot pożadania. Pobrano z: https://readeatslip.wordpress.com/2012/03/10/ ksiazka-przedmiot-pozadania-mickey-smith-volume-collocations/ (dostęp: 23.06.2016).

Kvist, Sannah. (2012). All I own. Pobrano z: http://www.sannahkvist.se/projects/all-i-own/ (dostęp: 15.06.2015).

Lebda, Małgorzata. (2013). Książka jako przedmiot pożądania. Fragile, 8. Pobrano z: http://www. fragile.net.pl/home/ksiazka-jako-przedmiot-pozadania (dostęp: 23.02.2017).

Lenart, Bonawentura. (1928). Piękna książka jako zestaw czynników materialnych, papieru, czcionek, ilustracji światłokowych, druki i oprawy. Wilno.

Martin, Henri, Jean, Chartier, Roger, Vivet, Jean-Pierre. (1983). Histoire de l'édition française, t. 3, Le temps des éditeurs, Du romantisme à la Belle Epoque (1830-1900). Paryż: Promodis.

Olsen, Bjørnar. (2010). W obronie rzeczy. Archeologia i ontologia przedmiotów. Tłum. Bożena Shallcross. Warszawa: Wydawnictwo IBL PAN.

Ośmiu słynnych bibliofilów $i$ ich biblioteki. Pobrano z: http://booklips.pl/zestawienia/8-slynnychbibliofilow-oraz-ich-domowe-biblioteki/ (dostęp: 22.02.2017).

Pięć wyjątkowych ksiązek. Pobrano z: http://wdowyibekarty.pl/piec-wyjatkowych-ksiazek (dostęp: 17.05.2016).

Skorupa, Ewa (2004). Polskie symbole kulturowe przed sądem pruskim 1871-1914:,, O podburzanie do gwałtów...”. Kraków: Universitas.

Sudjic, Dejan. (2013). Język rzeczy. W jaki sposób przedmioty nas uwodzą? Kraków: d2d.

Szwejkowska, Helena. (1987). Książa drukowana XV-XVIII wieku. Zarys historyczny. Warszawa: PWN.

The Bay Psalm Book Sale. Pobrano z: http://www.sothebys.com/en/auctions/2013/the-bay-psalmbook-sale-n09039.html\#\&i=0 (dostęp: 22.02.2017).

Tomasik, Ewa. (1994). Czytelnictwo i biblioterapia w pedagogice specjalnej, Warszawa: Wyższa Szkoła Pedagogiki Specjalnej im. Marii Grzegorzewskiej. 
Tschichold, Jan. (2011). Nowa typografia. Tłum. Eliza Borg. Łódź: Recto verso.

Uzanne, Octave. (1896). Dictionnaire bibliophilosophique, typologique, iconophilesque, bibliopegique et bibliotechnique à l'usage des bibliognostes, des bibliomanes et des bibliophilistins. Paryż: Paris Les Sociétaires de l'Académie des beaux livres.

Wichowa, Maria. (2003). Elementy biblioterapii w literaturze polskiej epok dawnych. Rekonesans historycznoliteracki. Acta Universitatis Lodzensis. Folia Librorum 17, s. 49-66.

Wiercińska, Janina. (1986). Sztuka i książka. Warszawa: PWN.

\section{STRESZCZENIE}

Zagadnienie „człowiek a książka” można z pewnością rozpatrywać na różnych płaszczyznach. W niniejszym artykule uwagę skupiono na historii książki, projektowania, a także kwestii pożądania książek, postrzegania ich jako dzieł sztuki czy obiektów kultu. Zaprezentowano zmiany, jakie kultura książki wnosiła i wnosi do życia społecznego. Starano się umieścić zainteresowanie książką w nurcie jednego ze zwrotów współczesnej humanistyki - zwrotu ku rzeczom, który, jak się wydaje, mógłby zostać rozpatrywany również w kategorii zwrotu ku książkom.

Słowa klucze: historia książki, projektowanie, książka jako obiekt pożądania

\section{SUMMARY}

The man and book paradigm in our history can be illustrated in a variety of ways. This paper focuses on the history of books and book design inspirations, with strong emphasis on introducing a book as an object of desire, art and culture. Moreover, this paper highlights the importance of the book culture as well as its past and present impact on our social life. The interest in books is placed in a concept of one of the so-called turns in the humanities - the turn to things, which in a specific way, can be understood as the turn to books.

Keywords: history of books, design, book as an object of desire 
Bibliobibule One who reads too much

Biblioclast One who tears pages from or otherwise destroys books

Bibliodemon A book fiend or demon

Bibliognoste One who is knowledgeable about editions, colophons, printers, and all the minutiae of books

Bibliographe One who describes books

Biblioklept One who steals books

Bibliolater One who worships books

Bibliolestes A book robber or plunderer

Bibliomancer One who practices divination by books

Bibliomane One who accumulates books indiscriminately

Bibliomaniac A book lover gone mad

Bibliophage One who eats or devours books

Bibliophile One who loves books

Bibliophobe One who fears books

Bibliopole One who sells books

Biblioriptos One who throws books around

Bibliosopher One who gains wisdom from books

Bibliotaphe One who buries or hides books

1. Ukucie nowych pojęć związanych z bibliofilstwem 


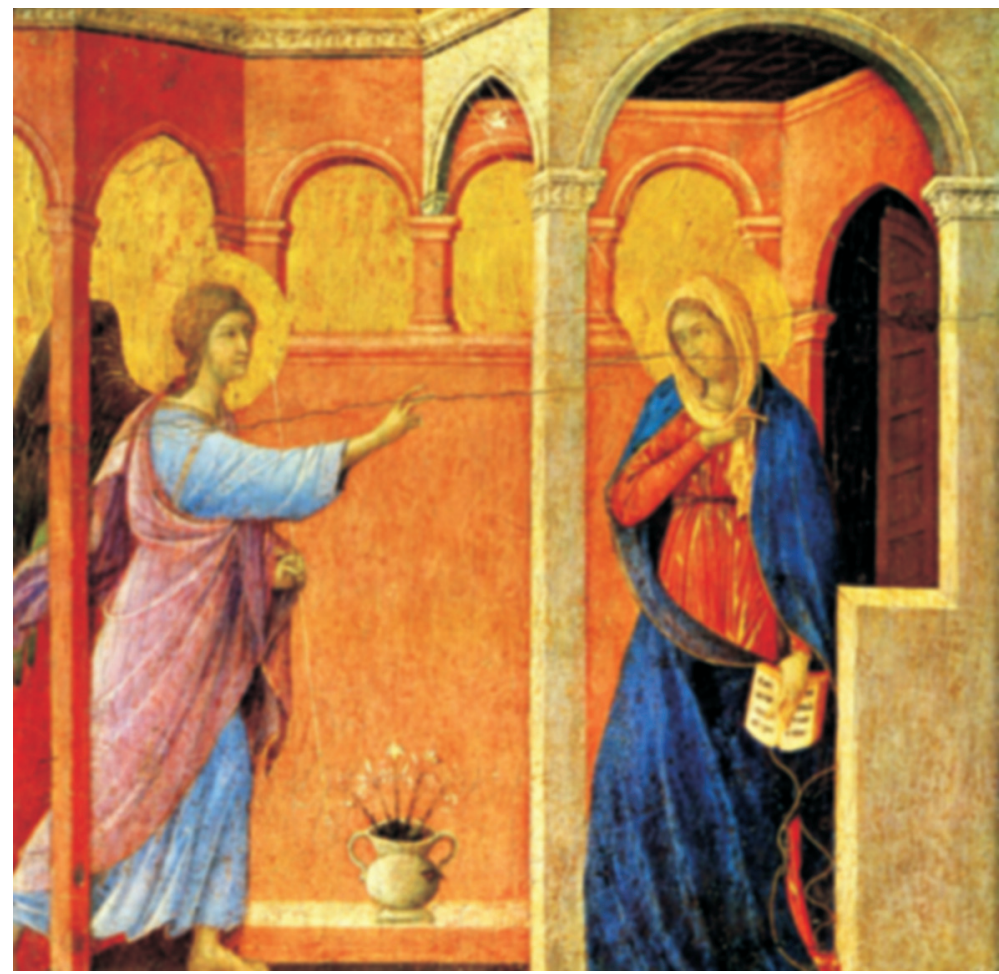

2. Duccio di Buoninsegna, Zwiastowanie, 1308-1311 (fragment poliptyku)

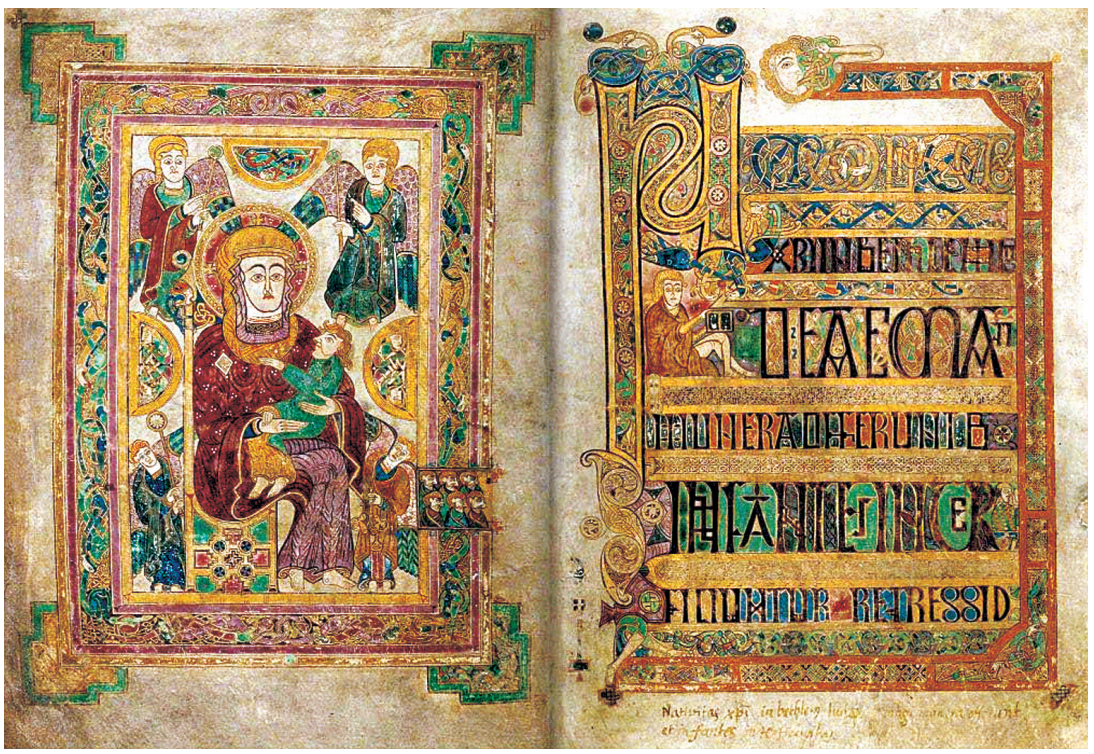

3. Ewangeliarz z Kells, ok. 800 roku 

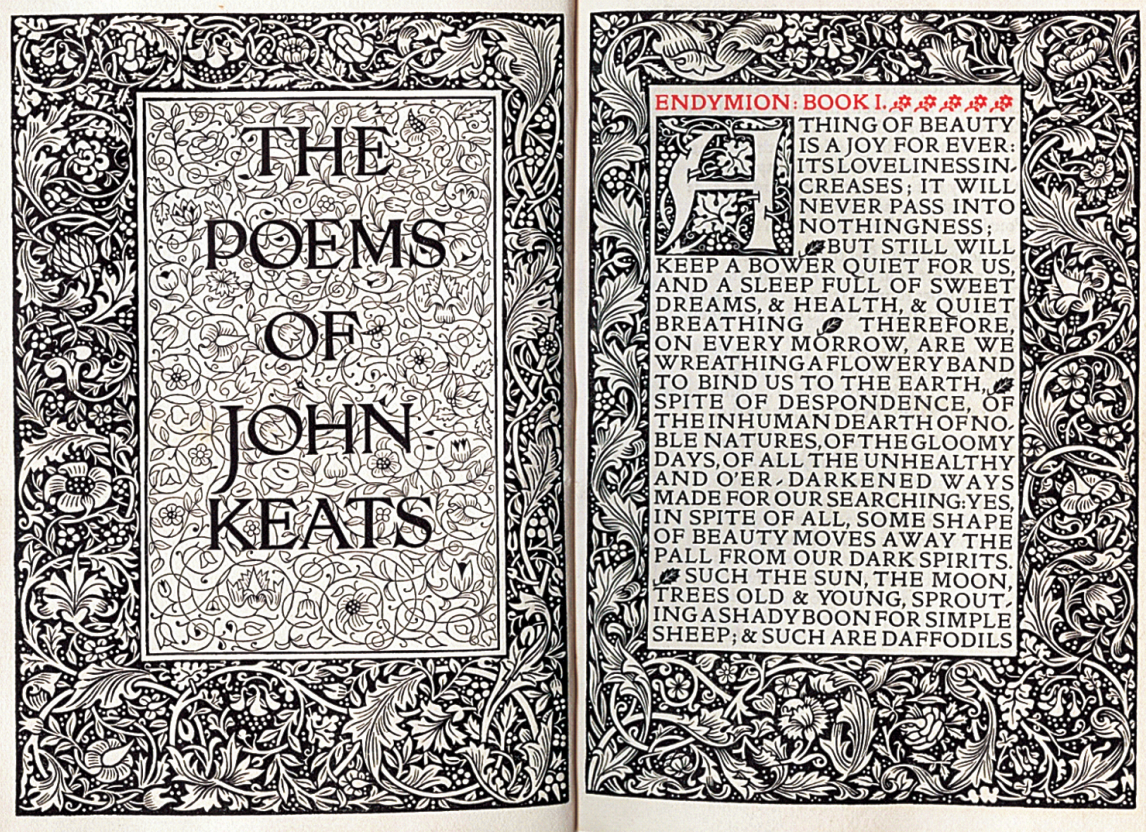

4. Jedna z prac Williama Morrisa, 1894 rok

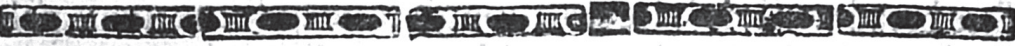

\section{OF THE DIVERS kindes of Drinke.}

\section{SECT.II.}

Whather it be wholfome for Northerne people, that inbabite colde countries, to drinke water at their meales, infead of Beare?

L though water be the molt ancient drinke, (1) and to thofe that inhabite hot Countries profitable and familiar, by reafon of the parching heate of the ambient aire, which 1. 1 doth exceedingly heate, in flame, and drs Their bodies; yet to fuch as inhabite colde

5. Przebijanie farby w druku z 1660 roku 


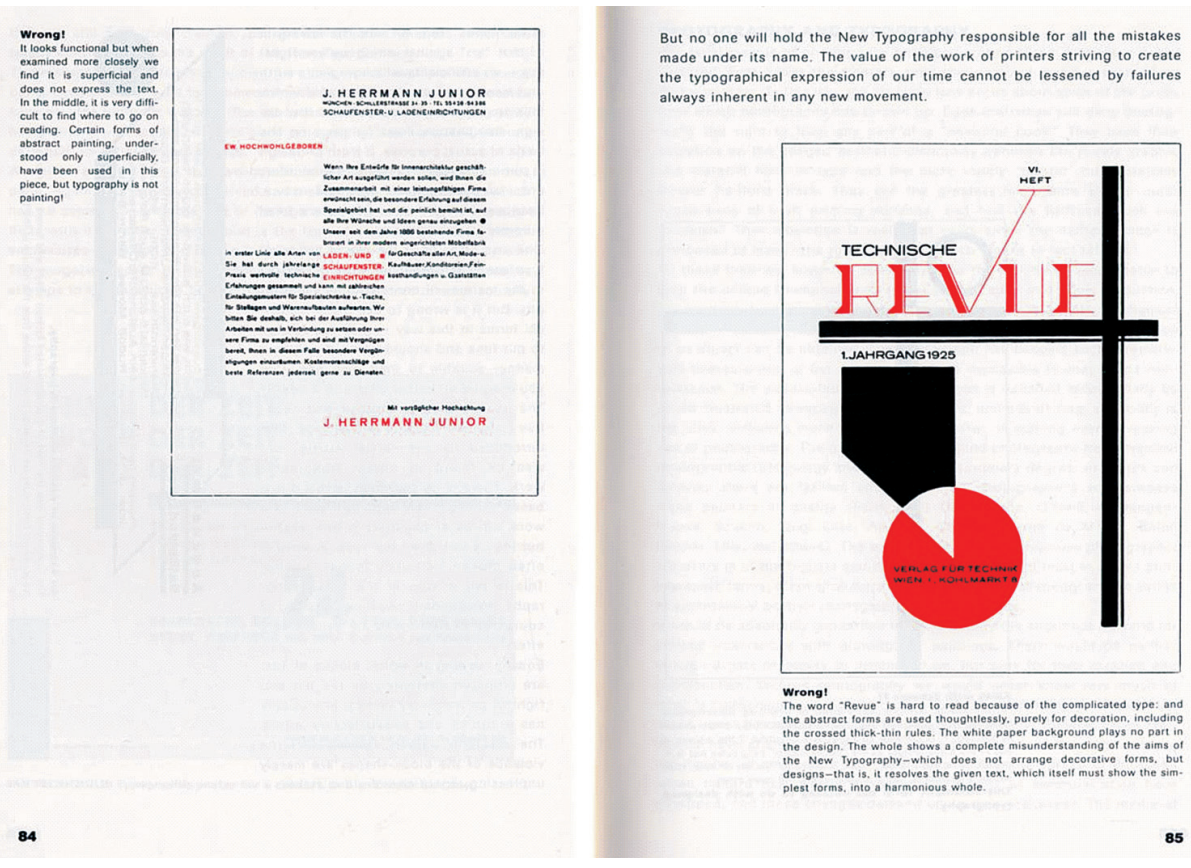

6. Modernistyczna stronica autorstwa Jana Tschicholda, 1928 rok
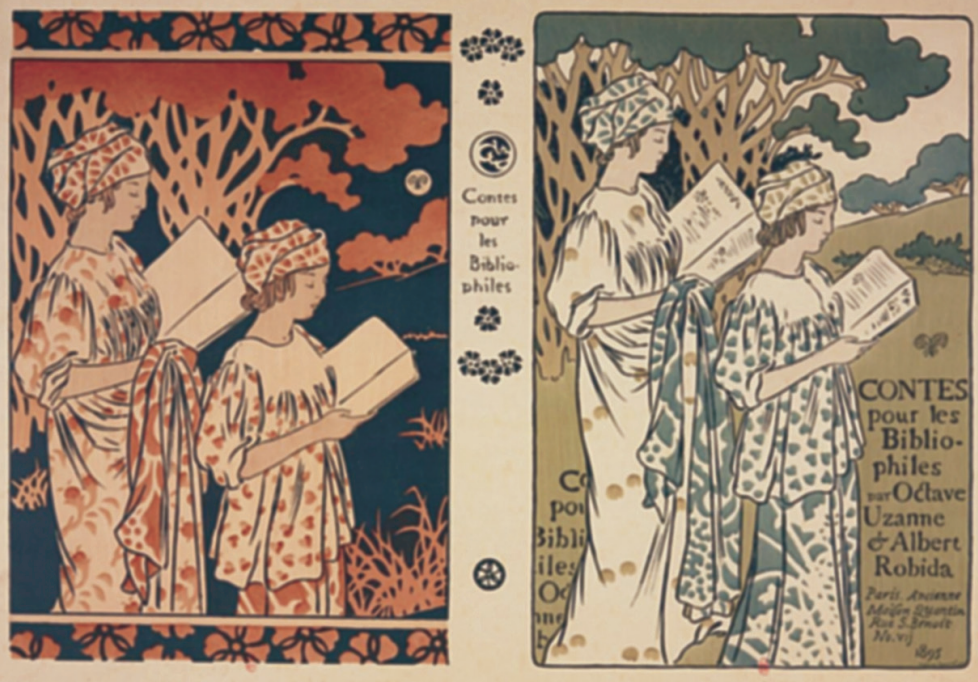

7. Okładka Opowieści dla bibliofilów Octave’a Uzanne’a, 1895 rok 